\title{
Publisher Correction to: A Constructional Approach to the Use of Behavior Change Projects in Undergraduate Behavior Analysis
} Courses

\author{
Brennan P. Armshaw ${ }^{1}$ - Traci M. Cihon ${ }^{1} \cdot$ Carlos Lopez $^{1}$
}

Published online: 6 January 2022

(c) Association for Behavior Analysis International 2021

Publisher Correction to: Behavior Analysis in Practice https://doi.org/10.1007/s40617-021-00608-1

Due to an error in production, this article was updated to correct the figures and in-text citations.

Publisher's Note Springer Nature remains neutral with regard to jurisdictional claims in published maps and institutional affiliations.

The original article can be found online at https://doi.org/10.1007/ s40617-021-00608-1.

Traci M. Cihon

traci.cihon@unt.edu

1 Department of Behavior Analysis, University of North

Texas, 1155 Union Circle \#310919, Denton, TX 762013,

USA 